\title{
Hematopoietic Progenitor Cell Transplantation in Children, Adolescents, and Young Adults With Relapsed Mature B-Cell NHL
}

\author{
Aliza Gardenswartz, MD, ${ }^{a}$ and Mitchell S. Cairo, MD ${ }^{a, b, c, d, e}$
}

\section{ABSTRACT}

Although children, adolescents, and young adults with newly diagnosed B-cell non-Hodgkin's lymphoma enjoy excellent overall survival with current chemoimmunotherapy, those with relapsed and/or refractory disease have a dismal prognosis. Although most clinicians would agree that hematopoietic progenitor cell transplantation after reinduction therapy is frontline therapy for these patients, there is no consensus as to what type of hematopoietic progenitor cell transplantation promises the best event-free and overall survival. This review outlines the disparate types of stem cell therapy that have been used in this difficult-to-treat population as well as the role of maintenance and CAR T-cell therapy in conjunction with stem cell therapy.

J Natl Compr Canc Netw 2020;18(8):1135-1142 doi: $10.6004 /$ jnccn.2020.7617

Departments of apediatrics, ${ }^{b}$ Pathology, ${ }^{c}$ Medicine, ${ }^{\mathrm{d}}$ Microbiology and Immunology, and ${ }^{\mathrm{e} C e l l}$ Biology and Anatomy, Maria Fareri Children's Hospital at Westchester Medical Center, New York Medical College, Valhalla, New York.
Children, adolescents, and young adults (CAYAs) with newly diagnosed B-cell non-Hodgkin's lymphoma (B-NHL) enjoy excellent overall survival (OS) with current frontline chemoimmunotherapy. ${ }^{1-3}$ However, those with relapsed and/or refractory $(\mathrm{R} / \mathrm{R})$ disease have had a historically dismal OS of $\leq 30 \%$ despite reinduction therapy and autologous hematopoietic progenitor cell transplantation (autoHCT) (Figure 1)., ${ }^{1,2,4-6}$ Specifically, patients with lactate dehydrogenase $\geq 2$ times the upper limit of normal (ULN) at diagnosis, R/R disease within 6 months of diagnosis, multisite relapse, and/or R/R disease with bone marrow involvement experience a significantly decreased OS (Table 1)..$^{1,7}$ Consensus guidelines in this difficult-totreat population are challenging to create given the small numbers of patients and multiple treatment options in this era of burgeoning cellular and immunotherapy. HCT, whether it be autologous, allogeneic, or tandem, has been and continues to be an integral part of therapy, with varying outcomes as delineated in Table 2. This review outlines autologous, allogeneic, tandem HCT; maintenance therapy after stem cell transplantation; and the role of CAR T-cell therapy as it relates to HCT as therapies for R/R B-NHL.

\section{Autologous Transplantation}

AutoHCT has historically been considered frontline therapy for CAYAs with R/R B-NHL. ${ }^{8,9}$ Gross et $\mathrm{al}^{5}$ conducted a Center for International Blood and Marrow Transplant Research (CIBMTR) retrospective study on CAYAs aged $\leq 18$ years with R/R B-NHL who underwent autologous $(n=90)$ or allogeneic $(n=92)$ HCT in 1990 through 2005. The 5-year event-free survival (EFS) rate was similar after autoHCT versus allogeneic HCT (alloHCT) in diffuse large B-cell lymphoma (DLBCL) (52\% vs $50 \%$ ), Burkitt lymphoma (27\% vs $31 \%$ ), and anaplastic large cell lymphoma ( $35 \%$ vs $46 \%$ ). In the Children's Oncology Group prospective study designed to determine the safety and efficacy of CBV (cyclophosphamide/carmustine/ etoposide) conditioning and autologous peripheral blood 


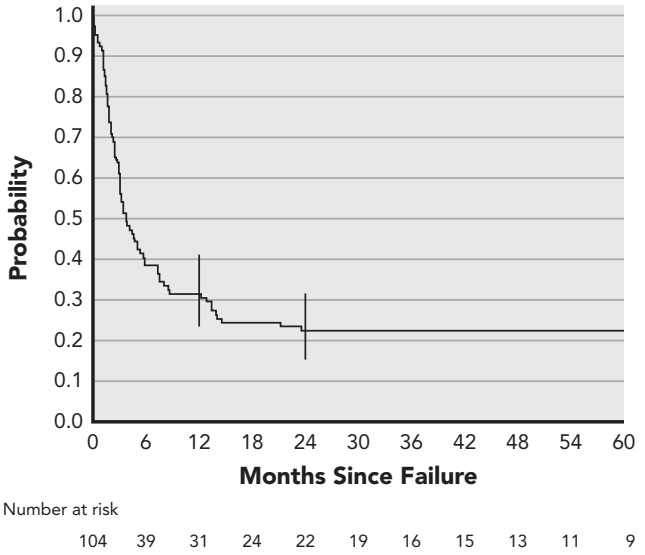

Figure 1. Kaplan-Meier curve showing probability of overall survival in children and adolescents with mature B-cell non-Hodgkin's lymphoma with refractory or relapsed disease during or after therapy in the FAB/LMB96 international study.

From Cairo M, Auperin A, Perkins SL, et al. Overall survival of children and adolescents with mature $B$ cell non-Hodgkin lymphoma who had refractory or relapsed disease during or after treatment with $F A B / L M B$ 96: a report from the FAB/LMB 96 study group. Br J Haematol 2018;182:859-869, used with permission from John Wiley \& Sons.

HCT in children with R/R Hodgkin lymphoma (HL) and NHL, the 3-year EFS rate from study entry for the 30 patients with NHL was only $30 \%$, whereas the 3-year OS for the 10 patients with NHL who underwent autoHCT was $70 \%{ }^{6}$ Burkhardt et $\mathrm{al}^{10}$ conducted a retrospective study of CAYAs aged $<18$ years diagnosed with NHL (excluding anaplastic large cell lymphoma) in or after January 2000 in 24 participating countries who had relapsed or refractory disease. Although survival for the 241 patients who did not undergo HCT was a dismal $9 \% \pm 2$, survival for the 153 patients treated with autoHCT was $55 \% \pm 5$.

\section{Allogeneic Transplantation}

AlloHCT is now being used in disparate centers as first-line therapy after salvage therapy for patients with R/R B-NHL. ${ }^{11}$ Although alloHCT offers the benefit of a graft-versus-lymphoma (GvL) effect, transplant-related mortality and risk of graft-versus-host disease (GVHD) are the weightiest disadvantages to be considered. Many clinicians favor alloHCT for lymphoblastic lymphoma. ${ }^{12}$ The aforementioned CIBMTR study revealed a markedly increased 5-year EFS rate of $40 \%$ in the patients with lymphoblastic lymphoma who underwent alloHCT compared with $4 \%$ in those who underwent autoHCT. ${ }^{5}$ Naik et al $^{11}$ recently published their institution's experience with allogeneic transplantation for $\mathrm{R} / \mathrm{R}$ pediatric NHL regardless of subtype in 36 patients, reporting 3-year OS and disease-free survival rates of $67 \%$ and $68 \%$, respectively. The 248 patients treated with alloHCT in the Burkhardt et $\mathrm{al}^{10}$ international study experienced an OS of $48 \% \pm 3$. The 5 -year cumulative incidences of transplant-related mortality and death from disease were $16 \% \pm 2$ and $34 \% \pm 3$, respectively.

\section{Tandem Transplantation}

\section{Tandem Autologous}

There is adult literature suggesting that tandem autologous transplantation may improve outcomes in patients with R/R HL. ${ }^{13-15}$ There are only 2 studies evaluating tandem autologous transplantation in NHL, both in the adult literature. Although the trial conducted by the GOELAMS group did include patients aged 15 to 60 years, it was an upfront trial in patients with poor-risk NHL; patients with Burkitt's, transformed low-grade, lymphoblastic, or mantle-cell lymphoma were therefore excluded. The study enrolled 45 patients and 31 completed the tandem high-dose therapy autoHCT, with an OS and EFS of $51 \%$ and $53 \%$, respectively, and 4 toxic deaths. ${ }^{16}$ Hohloch et $\mathrm{al}^{17}$ conducted a phase II trial of tandem autologous transplantation with interim myeloablative radioimmunotherapy with $\left.{ }^{[31} \mathrm{I}\right] \mathrm{anti}-\mathrm{CD} 20$ antibody in 16 adults with R/R lymphoma; 7 were unable to undergo radioimmunotherapy due to toxicity or progressive disease. The 4-year OS and progression-free survival (PFS) rates were $67 \%$ and $64 \%$, respectively. Hohloch et al ${ }^{18}$ subsequently conducted a prospective multicenter study using modified carmustine/etoposide/cytarabine/melphalan (BEAM) with triple autologous transplantation in adults with R/R NHL. Only 16 of the 24 evaluated patients completed therapy in accordance with the protocol, and 8 had to cease therapy secondary to grade III/IV toxicities. The 1- and 3-year EFS rates for all patients were $38 \%$ and $33 \%$, respectively, and the 1- and 3-year OS rates were $50 \%$ and $38 \%$, respectively. The trial was terminated early due to toxicity.

\section{Tandem Autologous and Allogeneic}

Tandem myeloablative conditioning autoHCT followed by reduced-intensity conditioning (RIC) allogeneic transplantation harnesses the strengths of both autoHCT and alloHCT. AutoHCT provides the benefit of disease eradication with myeloablative therapy. RIC alloHCT provides a GvL effect, with less transplant-related mortality. Carella et $\mathrm{al}^{19}$ premiered this approach in adult patients with $\mathrm{R} / \mathrm{R}$ lymphoma. In their cohort of 15 patients (10 HL and $5 \mathrm{NHL}$ ), 11 experienced a complete response, 9 of whom had only achieved a partial response after autoHCT. Crocchiolo et $\mathrm{al}^{20}$ reported a $68 \% 5$-year PFS in 34 patients with high-risk relapsed NHL who underwent tandem autoHCT followed by alloHCT at 2 centers in Italy. In a larger retrospective analysis of 111 patients with high-risk 


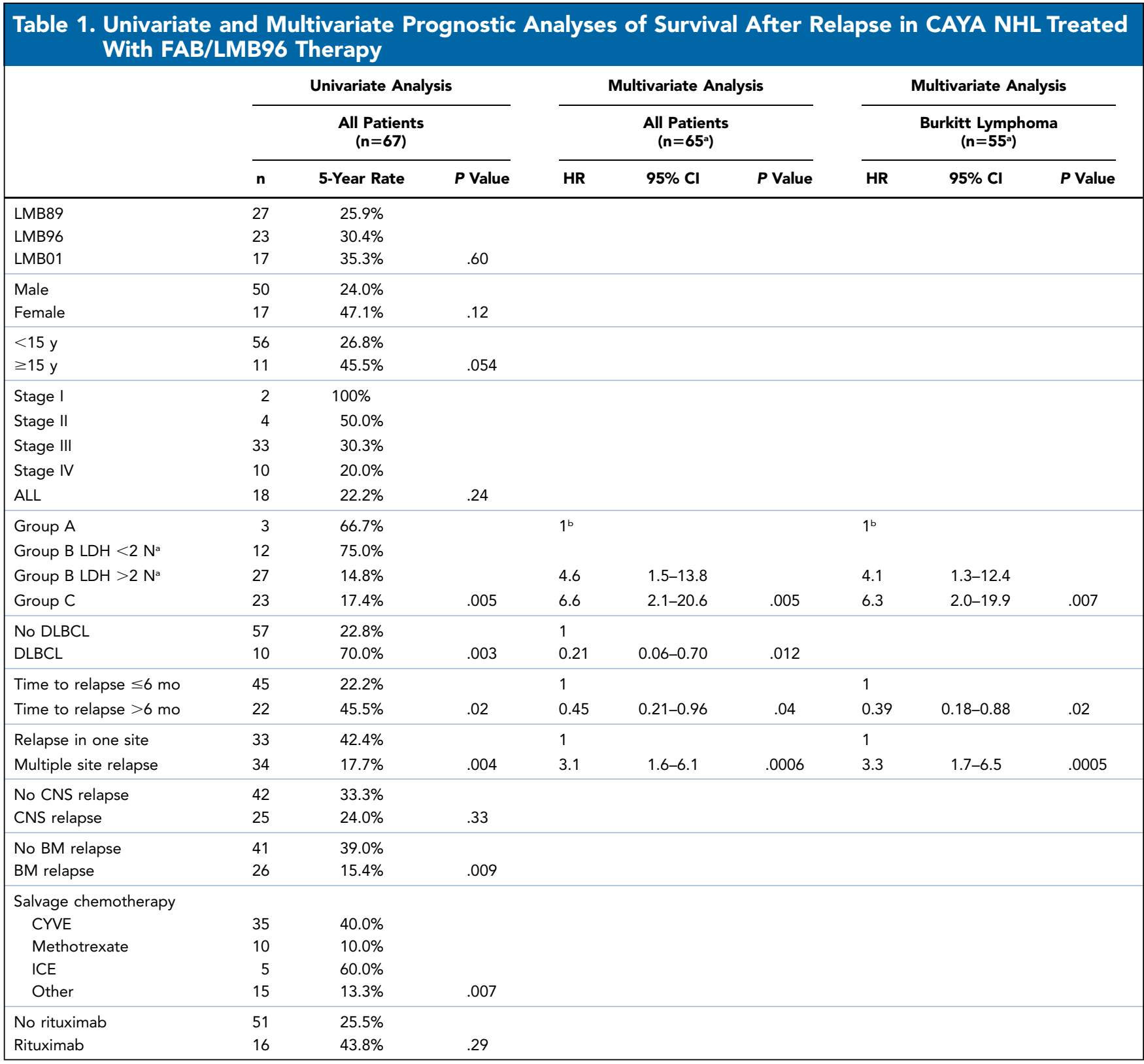

Abbreviations: ALL, acute lymphoblastic leukemia; BM, bone marrow; CAYA, childhood, adolescent, and young adult; CNS, central nervous system; CYVE, cytarabine with etoposide; DLBCL, diffuse large B-cell lymphoma; HR, hazard ratio; ICE, ifosfamide/carboplatin/etoposide; LDH, lactate dehydrogenase; N, upper limit of normal; NHL, non-Hodgkin's lymphoma.

aLDH missing for 2 patients of group $B$.

${ }^{b}$ Reference category is patients of group $A$ and group $B$ LDH $<2 \mathrm{~N}$

From Jourdain A, Auperin A, Minard-Colin V, et al. Outcome of and prognostic factors for relapse in children and adolescents with mature B-cell lymphoma and leukemia treated in three consecutive prospective "Lymphomes Malins B" protocols. A Société Française des Cancers de l'Enfant study. Haematologica 2015;100: 813 , with permission.

lymphoma who underwent tandem autoHCT followed by alloHCT, Crocchiolo et $\mathrm{al}^{21}$ again proved the safety and efficacy of this approach, reporting that the 39 patients with aggressive NHL and chemosensitive disease obtained a 3 -year PFS of $65 \%$. Chen et $\mathrm{al}^{22}$ reported the largest prospective series to date of tandem autoHCT followed by alloHCT in high-risk lymphoma. Among the
42 patients enrolled in their study, 29 (69\%) underwent an RIC alloHCT after their myeloablative conditioning autoHCTs. The 2-year PFS and OS rates for patients who underwent tandem HCT were previously unprecedented in this group, at $72 \%$ and $89 \%$, respectively. Our group pioneered this approach in CAYAs with $R / R$ lymphoma in a prospective study using myeloablative 
Table 2. HCT in Children, Adolescents, and Young Adults With Relapsed/Refractory NHL

\begin{tabular}{|c|c|c|c|c|c|c|c|}
\hline Author & $\begin{array}{l}\text { Center/ } \\
\text { Group }\end{array}$ & $\mathbf{N}$ & $\begin{array}{l}\text { Age } \\
\text { (y) }\end{array}$ & $\begin{array}{l}\text { NHL } \\
\text { Histology }\end{array}$ & $\begin{array}{l}\text { Donor } \\
\text { Source }\end{array}$ & $\begin{array}{l}\text { Conditioning } \\
\text { Regimen }\end{array}$ & $\begin{array}{c}\text { DFS/EFS } \\
\text { (\%) }\end{array}$ \\
\hline Philip et al, $1988^{47}$ & SFOP & 15 & NA & $\mathrm{B}-\mathrm{NHL}$ & $\begin{array}{l}14 \text { auto } \\
1 \text { allo }\end{array}$ & $\begin{array}{l}\text { BEAM/BEAC } \\
\text { Other }\end{array}$ & 27 \\
\hline Loiseau et al, $1991^{48}$ & $\begin{array}{l}\text { Institut Gustave } \\
\text { Roussy }\end{array}$ & 24 & NA & $\begin{array}{l}16 \mathrm{~B}-\mathrm{NHL} \\
8 \mathrm{~T}-\mathrm{NHL}\end{array}$ & Auto & $\begin{array}{l}\text { BU/CY } \\
\text { BU/Melphalan }\end{array}$ & 33 \\
\hline Bureo et al, $1995^{49}$ & Spain & 46 & $1-17$ & $\begin{array}{l}21 \mathrm{LL} \\
19 \mathrm{~B}-\mathrm{NHL} \\
6 \mathrm{LCL}\end{array}$ & $\begin{array}{l}14 \text { allo } \\
32 \text { auto }\end{array}$ & $\begin{array}{l}\text { BEAM } \\
\text { CY/TBI } \\
\text { CY/TBI/Ara-C }\end{array}$ & 58 \\
\hline Ladenstein et al, $1997^{50}$ & EBMT & 89 & $2.8-16.2$ & $\mathrm{~B}-\mathrm{NHL}$ & Auto & $\begin{array}{l}\text { BACT } 31 \\
\text { BEAM } 23 \\
\text { BU/CY } 9 \\
\text { Other } 26\end{array}$ & $\begin{array}{c}44 \\
\text { (sensitive relapse) }\end{array}$ \\
\hline Fanin et al, $1999^{51}$ & EBMT & 64 & $3.2-53$ & $\mathrm{ALCL}$ & Auto & $\mathrm{N} / \mathrm{A}$ & 47 \\
\hline Kobrinsky et al, $2001^{52}$ & CCG & 50 & $<21$ & $\mathrm{~N} / \mathrm{A}$ & Auto & $\mathrm{N} / \mathrm{A}$ & 50 \\
\hline Levine et al, $2003^{53}$ & CIBMTR & 128 & $2-67$ & LL & Auto & $\mathrm{N} / \mathrm{A}$ & 39 \\
\hline Woessmann et al, $2006^{54}$ & BFM & 20 & $1-15.8$ & $\mathrm{ALCL}$ & Allo & TBI/CY/VP-16 & 75 \\
\hline Won et al, $2006^{55}$ & Korea & $\begin{array}{l}33 \\
76\end{array}$ & $\begin{array}{l}1.7-16 \\
5-53\end{array}$ & $\begin{array}{l}6 \mathrm{~B}-\mathrm{NHL} \\
13 \mathrm{LL} \\
14 \mathrm{LCL}\end{array}$ & $\begin{array}{l}\text { Auto } \\
\text { Allo }\end{array}$ & $\begin{array}{l}\text { BEAM } \\
\text { BEAC } \\
\text { CBV } \\
\text { TBI regimen } \\
\text { N/A }\end{array}$ & $\begin{array}{l}59 \\
36\end{array}$ \\
\hline Gross et al, $2010^{5}$ & CIBMTR & $\begin{array}{l}90 \\
92\end{array}$ & & $\begin{array}{l}52 \mathrm{DLBCL} \\
53 \mathrm{LL} \\
41 \mathrm{BL} \\
36 \mathrm{ALCL}\end{array}$ & $\begin{array}{l}90 \text { auto } \\
92 \text { allo }\end{array}$ & NA & $\begin{array}{l}\text { DLBCL } \\
52 \text { (auto) } \\
50 \text { (allo) } \\
\text { BL } \\
27 \text { (auto) } \\
31 \text { (allo) } \\
\text { ALCL } \\
35 \text { (auto) } \\
46 \text { (allo) } \\
\text { LL } \\
4 \text { (auto) } \\
40 \text { (allo) }\end{array}$ \\
\hline Harris et al, $2011^{\circ}$ & COG & 10 & $4.2-19.9$ & NA & Auto & CBV & 70 \\
\hline Giulino-Roth et al, $2013^{56}$ & MSKCC (US) & $\begin{array}{l}21 \\
15\end{array}$ & $3.5-20.9$ & $\begin{array}{l}12 \mathrm{LL} \\
5 \mathrm{BL} \\
4 \mathrm{DLBCL} \\
13 \mathrm{ALCL} \\
1 \mathrm{PTCL} \\
1 \mathrm{u}-\mathrm{NHL}\end{array}$ & $\begin{array}{l}21 \text { allo } \\
15 \text { auto }\end{array}$ & $\begin{array}{l}\text { CY/TBI } \\
\text { CY/THIO/TBI } \\
\text { TBI/other } \\
\text { Non-TBI-based }\end{array}$ & 53 \\
\hline Jourdain et al, $2015^{7}$ & SFOP & $\begin{array}{r}33 \\
8\end{array}$ & NA & NA & $\begin{array}{l}8 \text { allo } \\
33 \text { auto }\end{array}$ & $\begin{array}{l}\text { BEAM, } \\
\text { BAM, } \\
\text { BU/MEL, } \\
\text { TBI/CY, other }\end{array}$ & $\begin{array}{l}49 \text { (auto) } \\
38 \text { (allo) }\end{array}$ \\
\hline Satwani et al, $2015^{23}$ & Multicenter US trial & 10 & $7-33$ & $\begin{array}{l}3 \mathrm{ALCL} \\
2 \mathrm{DLBCL} \\
3 \mathrm{BL} \\
1 \mathrm{LL} \\
1 \mathrm{PTCL}\end{array}$ & $\begin{array}{l}\text { Tandem } \\
\text { Auto } \\
\text { Allo }\end{array}$ & $\begin{array}{l}\text { BEC (auto) } \\
\text { BU/FLU } \pm \text { rATG } \\
\text { (allo) }\end{array}$ & 70 \\
\hline Burkhardt et al, $2018^{10}$ & International trial & $\begin{array}{l}153 \\
248\end{array}$ & $0.3-18$ & $\begin{array}{l}152 \mathrm{BL} \\
101 \mathrm{~T}-\mathrm{LL} \\
\text { Remaining 148: DLBCL + } \\
\text { PMBL + B-LL + other }\end{array}$ & $\begin{array}{l}153 \text { auto } \\
248 \text { allo }\end{array}$ & NA & $\begin{array}{c}55 \text { (auto) } \\
47 \text { (allo) }\end{array}$ \\
\hline
\end{tabular}




\begin{tabular}{|c|c|c|c|c|c|c|c|}
\hline Author & $\begin{array}{l}\text { Center/ } \\
\text { Group }\end{array}$ & $\mathbf{N}$ & $\begin{array}{l}\text { Age } \\
\text { (y) }\end{array}$ & $\begin{array}{l}\text { NHL } \\
\text { Histology }\end{array}$ & $\begin{array}{l}\text { Donor } \\
\text { Source }\end{array}$ & $\begin{array}{l}\text { Conditioning } \\
\text { Regimen }\end{array}$ & $\begin{array}{c}\text { DFS/EFS } \\
\text { (\%) }\end{array}$ \\
\hline \multirow{3}{*}{$\begin{array}{l}\text { Gardenswartz et al, } \\
2018^{24}\end{array}$} & \multirow[t]{3}{*}{ Multicenter US trial } & \multirow[t]{3}{*}{13} & \multirow[t]{3}{*}{$7-33$} & $8 \mathrm{BL}$ & Tandem & BEC (auto) & \multirow[t]{3}{*}{91} \\
\hline & & & & $3 \mathrm{DLBCL}$ & Auto & $\begin{array}{l}\text { BU/FLU } \pm \text { rATG } \\
\text { (allo 12) }\end{array}$ & \\
\hline & & & & $2 \mathrm{PMBL}$ & Allo & BEAM (allo 1) & \\
\hline \multirow[t]{10}{*}{ Naik et al, $2019^{11}$} & \multirow[t]{10}{*}{$\mathrm{TCH}$} & \multirow[t]{10}{*}{36} & \multirow[t]{10}{*}{$4-24$} & $14 \mathrm{ALCL}$ & Allo & MAC 27 & \multirow[t]{10}{*}{68} \\
\hline & & & & $8 \mathrm{~T}-\mathrm{LL}$ & & RIC 9 & \\
\hline & & & & $1 \mathrm{~B}-\mathrm{LL}$ & & & \\
\hline & & & & $8 \mathrm{DLBCL}$ & & & \\
\hline & & & & $1 \mathrm{BL}$ & & & \\
\hline & & & & $\begin{array}{l}1 \text { small cell, non-Burkitt } \\
\text { high-grade lymphoma }\end{array}$ & & & \\
\hline & & & & $1 \mathrm{~T}$-cell-rich, B-cell lymphoma & & & \\
\hline & & & & $\begin{array}{l}1 \text { stem cell } \\
\text { myeloproliferative/T-cell } \\
\text { lymphoma }\end{array}$ & & & \\
\hline & & & & 1 hepatosplenic & & & \\
\hline & & & & $\gamma \delta$ T-cell lymphoma & & & \\
\hline
\end{tabular}

Abbreviations: ALCL, anaplastic large cell lymphoma; allo, allogeneic; Ara-c, cytarabine; B-LL, B-lymphoblastic lymphoma; BEAC, carmustine/etoposide/Ara-C/ cyclophosphamide; auto, autologous; BACT, bischloroethylnitrosourea/cytarabine/cyclophosphamide/6-thioguanine; BAM, busulfan/cytarabine/melphalan; BEAM, carmustine/etoposide/cytarabine/melphalan; BEC, carmustine/etoposide/cyclophosphamide; BFM, Berlin-Frankfurt-Münster; BL, Burkitt lymphoma; B-NHL, B-cell non-Hodgkin's lymphoma; BU, busulfan; CBV, cyclophosphamide/carmustine/etoposide (VP-16); CCG, Children's Cancer Group; COG, Children's Oncology Group; CY, cyclophosphamide; CIBMTR, Center for International Bone Marrow Transplant Registry; DFS, disease-free survival; DLBCL, diffuse large B-cell lymphoma; EBMT, European Society for Blood and Marrow Transplantation; EFS, event-free survival; FLU, fludarabine; HCT, hematopoietic progenitor cell transplantation; LCL, large cell lymphoma; LL, lymphoblastic lymphoma; MAC, myeloablative conditioning; MEL, melphalan; MSKCC, Memorial Sloan Kettering Cancer Center; N, number; NA, not available; N/A, not applicable; NHL, non-Hodgkin's lymphoma; PMBL, primary mediastinal B-cell lymphoma; PTCL, peripheral T-cell lymphoma; rATG, rabbit antithymocyte globulin; RIC, reduced-intensity conditioning; SFOP, Société Française di'Oncologie Pédiatrique; TBI, total body irradiation; TCH, Texas Children's Hospital; T-LL, T-lymphoblastic lymphoma; T-NHL, T-cell non-Hodgkin's lymphoma; THIO, thiotepa; u-NHL, undifferentiated NHL; VP-16, etoposide.

Modified from Bradley MB, Cairo MS. Stem cell transplantation for pediatric lymphoma: past, present and future. Bone Marrow Transplant 2008;41:150; with permission.

conditioning autoHCT with subsequent RIC alloHCT, ${ }^{23}$ reporting an overall 10 -year EFS of $50 \%$ in an intent-totreat analysis of all enrolled patients with HL versus a $70 \%$ EFS in patients who received a tandem myeloablative conditioning autoHCT and RIC alloHCT. We have reported a $91 \%$ EFS in a cohort of 13 CAYA patients with R/R B-NHL (5 of whom were part of our original cohort) who underwent myeloablative conditioning autoHCT with subsequent radioimmunotherapy with yttrium-90-ibritumomab tiuxetan followed by RIC alloHCT with a median follow-up of 48 months. ${ }^{24}$ There were no reports of myelodysplastic syndromes or secondary leukemias and no transplant-related mortality in this cohort to date.

\section{Maintenance After HCT}

In this era of targeted, immune, and cellular therapy, there is a paradigm in patients with HL for a maintenance therapy regimen post HCT that offers promising results. The AETHERA trial revealed an almost $20 \%$ increase in PFS in patients with unfavorable-risk relapsed or primary refractory HL randomized to receive brentuximab vedotin (BV) post autoHCT compared with those who were randomized to the placebo arm. ${ }^{25}$ An expert panel comprising members of the American Society for Blood and Marrow Transplantation (now called American Society for Transplantation and Cellular Therapy), CIBMTR, and the European Society for Blood and Marrow Transplantation (EBMT) that recently convened to create consensus statements regarding maintenance therapies for HL and NHL endorsed BV maintenance and/or consolidation in BV-naïve high-risk $\mathrm{HL} .{ }^{26}$ In a recent case study, Flerlage et $\mathrm{al}^{27}$ described their retrospective review of 5 pediatric patients with R/R HL who received BV post autoHCT. All 5 patients were reported to be alive and in CR with a 29- to 76-month follow-up time from initiation of consolidation. The Collaborative Trial in Relapsed Aggressive Lymphoma randomized 242 patients post BEAM conditioning and autoHCT to either rituximab maintenance (every 2 months for 1 year) or observation and reported no difference in 4 -year EFS or OS between the 2 arms. ${ }^{28}$ Rituximab maintenance did yield an increased 10-year PFS in the phase III EBMT study that randomized patients with relapsed follicular lymphoma to either maintenance rituximab or observation ( $54 \%$ vs $37 \%$ ). This statistically significant PFS did not translate into a difference in OS. ${ }^{29}$ Rituximab maintenance therapy also proved efficacious for mantle cell lymphoma in a phase III study that randomized 240 patients to rituximab 
maintenance or observation post R-BEAM autoHCT. Patients in the rituximab maintenance arm experienced a 4 -year EFS, PFS, and OS of $79 \%, 83 \%$, and $89 \%$, respectively, compared with $61 \%, 64 \%$, and $80 \%$ in the observation arm $(P=.001) .{ }^{30}$ Myriad agents are being evaluated currently as maintenance therapies post autoHCT in adults with B-NHL, including ibrutinib, bortezomib, lenalidomide, and pembrolizumab. In their evaluation of ways to improve outcomes of autologous transplantations in lymphoma, Dahi et al ${ }^{13}$ deem maintenance therapy as having the most promise in attaining that goal.

\section{Polatuzumab Maintenance After HCT}

Polatuzumab vedotin (PV), an antibody-drug conjugate that targets CD79b antigens on the surface of human $\mathrm{B}$ cells and that is linked to monomethyl auristatin E (MMAE), a potent tubulin inhibitor, is a promising candidate for maintenance therapy in patients with B-NHL post HCT. Palanca-Wessels et $\mathrm{a}^{31}$ demonstrated that PV had an acceptable safety and tolerability profile in 68 patients with NHL. In addition, they went on to demonstrate an objective response in 23 of 42 evaluable patients given single-agent PV (specifically 14 of 25 with DLBCL) and 7 of 9 patients treated with PV and rituximab. A series of subsequent phase II studies used $\mathrm{PV}$ in combination with other chemotherapy agents, including in combination with rituximab, in patients with R/R DLBCL. Of the 39 patients enrolled in the rituximab plus PV arm in the ROMULUS study, 54\% had an objective response, whereas $21 \%$ had a CR. ${ }^{32}$ Sehn et $\mathrm{al}^{33}$ recently published their findings in patients aged $>18$ years with transplant-ineligible $R / R$ DLBCL treated with either PV plus bendamustine and rituximab (BR) versus PV plus bendamustine and obinutuzumab. The phase II 1:1 randomization comparing PV BR versus BR showed that CR rates were significantly higher (40\% vs $17.5 \%$ ) and risk of death was reduced by $58 \%$ in the PV BR group. PV was also studied up-front in newly diagnosed DLBCL in combination with chemotherapy. ${ }^{34} \mathrm{PV}$ is generally well tolerated. The most common grade 3-4 events reported in the single-agent study by Palanca-Wessels et $\mathrm{al}^{31}$ were neutropenia, anemia, and peripheral sensory neuropathy.

\section{CAR T-Cell Therapy Before and After HCT}

CAR T-cell therapy is changing the landscape of R/R NHL therapy. There are now 2 FDA-approved CARs for adult B-NHL. ${ }^{35,36}$ CARs are artificial receptors composed of an antigen-specific, monoclonal antibody-derived singlechain variable fragment bound to an intracellular signaling domain. Specifically directed CARs incorporated into $\mathrm{T}$ cells or natural killer cells create an opportunity for target-specific recognition to be combined with cellular activation. Potential advantages of CAR-based immunotherapy over monoclonal antibody therapy include diffuse biodistribution, stimulation of the adaptive immune system, and sustained immune activity (or a so-called living drug). ${ }^{37,38}$ Although 4-1BB CARs persist for a longer amount of time, CD28 CARs have faster and more robust expansion. ${ }^{39,40}$ Tisagenlecleucel and axicabtagene ciloleucel (axi-cel) are the 2 currently FDA-approved CAR therapies for DLBCL. Axi-cel is also FDA-approved for primary mediastinal B-cell lymphoma. ${ }^{35}$ Tisagenlecleucel is an anti-CD19 secondgeneration CAR with a 4-1BB costimulatory domain. In the phase II JULIET trial, $40 \%$ of the 93 adults who underwent infusion had a CR and $12 \%$ a partial response (PR); 12 months after initial response, relapsefree survival was $65 \% .^{41}$ Axicabtagene ciloleucel is an anti-CD19 second-generation CAR with a CD28 costimulatory domain. In the phase II ZUMA trial, $54 \%$ of the 101 patients who underwent infusion experienced a CR and $28 \%$ a PR. ${ }^{42}$ There are no currently FDA-approved CARs for pediatric NHL. Rivers et $\mathrm{al}^{43}$ presented 8 pediatric patients receiving CAR-T therapy as 1:1 ratio of CD4 and CD8 cells for DLBCL, primary mediastinal B-cell lymphoma, Burkitt lymphoma, and gray zone lymphoma. Only 3 of 8 patients experienced a CR, whereas 5 of 8 experienced a CR or PR; however, the CRs were not sustained. The NIH currently has an anti-CD22 CAR T-cell therapy trial open for pediatric patients with recurrent/refractory CD22-expressing B-cell malignancies (ClinicalTrials.gov identifier: NCT02315612).

In a pooled analysis of published CD19 CAR T-cell therapy in patients with $B$ acute lymphoblastic leukemia, Taraseviciute et $\mathrm{al}^{44}$ note that a greater number of relapses occurred in patients who did not proceed to HCT after CAR T-cell therapy. Although CAR T-cell therapy can be used as a bridge to transplant, the CAR T-cells are then eradicated with pretransplant conditioning. Providing CAR T-cells in conjunction with alloHCT is an appealing prospect because they can immediately provide a GvL effect and serve as bridging therapy until immune reconstitution post HCT occurs and the GvL from the allograft takes effect, although there is some concern that immunosuppression post alloHCT might affect the efficacy of CAR T-cells. ${ }^{44}$ Kochenderfer et $\mathrm{al}^{45}$ treated 10 patients with CD19-positive NHL post alloHCT whose disease did not respond to standard-donor lymphocyte infusions with donor-derived CD19 CAR-T cells. Two patients with chronic lymphocytic leukemia achieved a CR and 1 patient with mantle cell lymphoma achieved a PR; none of the 10 patients developed GVHD. Kochenderfer's group ${ }^{46}$ went on to treat 20 patients with CD19-positive NHL post alloHCT with donor-derived 
CD19 CAR-T cells; 6 achieved a CR and 2 a PR. Not one of the 20 patients developed GVHD.

\section{Conclusions}

In this thrilling age of rapidly evolving cellular and immune therapy, there is a cornucopia of therapeutic combinations to choose from in CAYAs with R/R B-NHL. Given the small group of patients who experience disease relapse, it is difficult to design randomized controlled trials to compare all of these options. Despite the promising response rates to CD19 CAR T-cell therapy in adults with R/R B-NHL, there are limited data in CAYAs at this point and neither of the 2 FDAapproved CARs are indicated for Burkitt lymphoma, the most common subtype of pediatric B-NHL. Our standard approach includes reinduction therapy, and for those experiencing a PR/CR we proceed with myeloablative conditioning and autoHCT, including yttrium-90ibritumomab tiuxetan in the myeloablative conditioning, followed by an RIC alloHCT as we have previously described. ${ }^{24}$

\section{Acknowledgments}

The authors would like to thank Erin Morris, BSN, and Virginia Davenport, $\mathrm{RN}$, for their excellent assistance in the preparation of this manuscript.

\section{Submitted February 18, 2020; accepted for publication July 7, 2020.}

Disclosures: Dr. Gardenswartz has disclosed that she has no financial interests, arrangements, or affiliations with the manufacturers of any products discussed in this article or their competitors. Dr. Cairo has disclosed that he is a scientific advisor for, serves on the speaker's bureau for, and receives grant/research support from Jazz Pharmaceuticals; is a scientific advisor for Amgen; and serves on the speaker's bureau for and receives grant/research support from Servier.

Funding: This work was supported in part from grants from the Pediatric Cancer Research Foundation and 1U54 CA232561-01/A1.

Correspondence: Mitchell S. Cairo, MD, Maria Fareri Children's Hospital at Westchester Medical Center, New York Medical College, 40 Sunshine Cottage Road, Skyline Office 1N-D12, Valhalla, NY 10595.

Email: mitchell_cairo@nymc.edu

\section{References}

1. Cairo M, Auperin A, Perkins SL, et al. Overall survival of children and adolescents with mature $B$ cell non-Hodgkin lymphoma who had refractory or relapsed disease during or after treatment with $F A B / L M B$ 96: a report from the FAB/LMB 96 study group. Br J Haematol 2018;182:859-869.

2. Cairo MS, Sposto R, Gerrard M, et al. Advanced stage, increased lactate dehydrogenase, and primary site, but not adolescent age ( $\geq 15$ years), are associated with an increased risk of treatment failure in children and adolescents with mature B-cell non-Hodgkin's lymphoma: results of the FAB LMB 96 study. J Clin Oncol 2012;30:387-393.

3. Goldman S, Smith L, Galardy P, et al. Rituximab with chemotherapy in children and adolescents with central nervous system and/or bone marrow-positive Burkitt lymphoma/leukaemia: a Children's Oncology Group Report. Br J Haematol 2014;167:394-401.

4. Cairo MS, Gerrard M, Sposto R, et al. Results of a randomized international study of high-risk central nervous system $B$ non-Hodgkin lymphoma and $\mathrm{B}$ acute lymphoblastic leukemia in children and adolescents. Blood 2007; 109:2736-2743.

5. Gross TG, Hale GA, He W, et al. Hematopoietic stem cell transplantation for refractory or recurrent non-Hodgkin lymphoma in children and adolescents. Biol Blood Marrow Transplant 2010;16:223-230.

6. Harris RE, Termuhlen AM, Smith LM, et al. Autologous peripheral blood stem cell transplantation in children with refractory or relapsed lymphoma: results of Children's Oncology Group study A5962. Biol Blood Marrow Transplant 2011;17:249-258.

7. Jourdain A, Auperin A, Minard-Colin V, et al. Outcome of and prognostic factors for relapse in children and adolescents with mature B-cell lymphoma and leukemia treated in three consecutive prospective "Lymphomes Malins B" protocols. A Société Française des Cancers de l'Enfant study. Haematologica 2015;100:810-817.

8. Bradley MB, Cairo MS. Stem cell transplantation for pediatric lymphoma: past, present and future. Bone Marrow Transplant 2008;41:149-158

9. Cairo MS, Woessmann W, Pagel J. Advances in hematopoietic stem cell transplantation in childhood and adolescent lymphomas. Biol Blood Marrow Transplant 2013;19(1 Suppl)S38-43.

10. Burkhardt B, Pillon M, Taj M, et al. Role of HSCT in children and adolescents with refractory or relapsed $\mathrm{NHL}$ [abstract]. $\mathrm{Br} \mathrm{J}$ Haematol 2018;182(Suppl 1):Abstract 30.

11. Naik S, Martinez CA, Omer B, et al. Allogeneic hematopoietic stem cell transplant for relapsed and refractory non-Hodgkin lymphoma in pediatric patients. Blood Adv 2019;3:2689-2695.

12. Woessmann W. XI. How to treat children and adolescents with relapsed non-Hodgkin lymphoma? Hematol Oncol 2013;31(Suppl 1):64-68.
13. Dahi PB, Moskowitz CH, Giralt SA, et al. Novel agents may positively impact chemotherapy and transplantation in subsets of diffuse large B-cell lymphoma. Expert Rev Hematol 2019;12:407-418.

14. Smith EP, Li H, Friedberg JW, et al. Tandem autologous hematopoietic cell transplantation for patients with primary progressive or recurrent Hodgkin lymphoma: a SWOG and Blood and Marrow Transplant Clinical Trials Network phase II trial (SWOG S0410/BMT CTN 0703). Biol Blood Marrow Transplant 2018;24:700-707.

15. Morschhauser F, Brice $P$, Fermé $C$, et al. Risk-adapted salvage treatment with single or tandem autologous stem-cell transplantation for first relapse/refractory Hodgkin's lymphoma: results of the prospective multicenter $\mathrm{H} 96$ trial by the GELA/SFGM study group. J Clin Oncol 2008; 26:5980-5987.

16. Monjanel $H$, Deconinck $E$, Perrodeau $E$, et al. Long-term follow-up of tandem high-dose therapy with autologous stem cell support for adults with high-risk age-adjusted international prognostic index aggressive non-Hodgkin Lymphomas: a GOELAMS pilot study. Biol Blood Marrow Transplant 2011;17:935-940.

17. Hohloch K, Sahlmann CO, Lakhani VJ, et al. Tandem high-dose therapy in relapsed and refractory $\mathrm{B}$-cell lymphoma: results of a prospective phase II trial of myeloablative chemotherapy, followed by escalated radioimmunotherapy with (131)l-anti-CD20 antibody and stem cell rescue. Ann Hematol 2011;90:1307-1315.

18. Hohloch K, Zeynalova S, Chapuy B, et al. Modified BEAM with triple autologous stem cell transplantation for patients with relapsed aggressive non-Hodgkin lymphoma. Ann Hematol 2016;95:1121-1128.

19. Carella AM, Cavaliere M, Lerma $E$, et al. Autografting followed by nonmyeloablative immunosuppressive chemotherapy and allogeneic peripheral-blood hematopoietic stem-cell transplantation as treatment of resistant Hodgkin's disease and non-Hodgkin's lymphoma. J Clin Oncol 2000;18:3918-3924.

20. Crocchiolo R, Castagna L, Fürst $S$, et al. Tandem autologous-allo-SCT is feasible in patients with high-risk relapsed non-Hodgkin's lymphoma. Bone Marrow Transplant 2013;48:249-252.

21. Crocchiolo R, Castagna L, Garciaz S, et al. Tandem autologous-allogeneic stem cell transplantation as a feasible and effective procedure in high-risk lymphoma patients. Haematologica 2015;100:e423-427.

22. Chen YB, Li S, Fisher DC, et al. Phase II trial of tandem high-dose chemotherapy with autologous stem cell transplantation followed by reduced-intensity allogeneic stem cell transplantation for patients with high-risk lymphoma. Biol Blood Marrow Transplant 2015;21:1583-1588.

23. Satwani $\mathrm{P}$, Jin Z, Martin PL, et al. Sequential myeloablative autologous stem cell transplantation and reduced intensity allogeneic hematopoietic cell transplantation is safe and feasible in children, adolescents and young 
adults with poor-risk refractory or recurrent Hodgkin and non-Hodgkin lymphoma. Leukemia 2015;29:448-455

24. Gardenswartz A, Mehta B, El-Mallawany N, et al. Safety and efficacy of myeloablative conditioning autologous stem cell transplantation, targeted immunotherapy, and reduced intensity conditioning allogeneic stem cell transplantation in children, adolescents, and young adults with relapsed/refractory mature B-cell non Hodgkin lymphoma [abstract]. Br J Haematol 2018;182(Suppl 1):Abstract 28.

25. Moskowitz $\mathrm{CH}$, Nademanee A, Masszi $\mathrm{T}$, et al. Brentuximab vedotin as consolidation therapy after autologous stem-cell transplantation in patients with Hodgkin's lymphoma at risk of relapse or progression (AETHERA): a randomised, double-blind, placebo-controlled, phase 3 trial. Lancet 2015;385:1853-1862.

26. Kanate AS, Kumar A, Dreger $P$, et al. Maintenance therapies for Hodgkin and non-Hodgkin lymphomas after autologous transplantation: a consensus project of ASBMT, CIBMTR, and the Lymphoma Working Party of EBMT. JAMA Oncol 2019;5:715-722.

27. Flerlage JE, von Buttlar $\mathrm{X}$, Krasin $\mathrm{M}$, et al. Brentuximab vedotin as consolidation after hematopoietic cell transplant for relapsed Hodgkin lymphoma in pediatric patients. Pediatr Blood Cancer 2019;66:e27962.

28. Gisselbrecht C, Schmitz N, Mounier N, et al. Rituximab maintenance therapy after autologous stem-cell transplantation in patients with relapsed $\mathrm{CD} 2 \mathrm{O}(+)$ diffuse large B-cell lymphoma: final analysis of the Collaborative Trial in Relapsed Aggressive Lymphoma. J Clin Oncol 2012; 30:4462-4469.

29. Pettengell R, Schmitz N, Gisselbrecht $C$, et al. Rituximab purging and/or maintenance in patients undergoing autologous transplantation for relapsed follicular lymphoma: a prospective randomized trial from the lymphoma working party of the European group for blood and marrow transplantation. J Clin Oncol 2013;31:1624-1630.

30. Le Gouill S, Thieblemont C, Oberic L, et al. Rituximab after autologous stem-cell transplantation in mantle-cell lymphoma. N Engl J Med 2017; 377:1250-1260.

31. Palanca-Wessels MC, Czuczman M, Salles G, et al. Safety and activity of the anti-CD79B antibody-drug conjugate polatuzumab vedotin in relapsed or refractory B-cell non-Hodgkin lymphoma and chronic lymphocytic leukaemia: a phase 1 study. Lancet Oncol 2015;16:704-715.

32. Morschhauser F, Flinn IW, Advani R, et al. Polatuzumab vedotin or pinatuzumab vedotin plus rituximab in patients with relapsed or refractory non-Hodgkin lymphoma: final results from a phase 2 randomised study (ROMULUS). Lancet Haematol 2019;6:e254-265.

33. Sehn $L H$, Herrera AF, Flowers $C R$, et al. Polatuzumab vedotin in relapsed or refractory diffuse large B-cell lymphoma. J Clin Oncol 2020;38: 155-165.

34. Tilly $\mathrm{H}$, Morschhauser F, Bartlett NL, et al. Polatuzumab vedotin in combination with immunochemotherapy in patients with previously untreated diffuse large B-cell lymphoma: an open-label, non-randomised, phase 1b-2 study. Lancet Oncol 2019:20:998-1010.

35. Chavez JC, Bachmeier C, Kharfan-Dabaja MA. CAR T-cell therapy for B-cell lymphomas: clinical trial results of available products. Ther Adv Hematol 2019;10:2040620719841581.

36. Dave H, Jerkins L, Hanley PJ, et al. Driving the CAR to the bone marrow transplant program. Curr Hematol Malig Rep 2019;14:561-569.

37. Chu Y, Flower A, Cairo MS. Modification of expanded NK cells with chimeric antigen receptor mRNA for adoptive cellular therapy. Methods Mol Biol 2016;1441:215-230.

38. Batlevi CL, Matsuki E, Brentjens RJ, et al. Novel immunotherapies in lymphoid malignancies. Nat Rev Clin Oncol 2016;13:25-40.

39. van der Stegen SJ, Hamieh M, Sadelain M. The pharmacology of second-generation chimeric antigen receptors. Nat Rev Drug Discov 2015;14:499-509.

40. Chu Y, Gardenswartz A, Termuhlen AM, et al. Advances in cellular and humoral immunotherapy - implications for the treatment of poor risk childhood, adolescent, and young adult B-cell non-Hodgkin lymphoma. Br J Haematol 2019;185:1055-1070.
41. Schuster SJ, Bishop MR, Tam CS, et al. Tisagenlecleucel in adult relapsed or refractory diffuse large B-cell lymphoma. N Engl J Med 2019;380: 45-56.

42. Locke FL, Ghobadi A, Jacobson CA, et al. Long-term safety and activity of axicabtagene ciloleucel in refractory large B-cell lymphoma (ZUMA-1): a single-arm, multicentre, phase 1-2 trial. Lancet Oncol 2019, 20:31-42.

43. Rivers J, Annesley C, Summers C, et al. Early response data for pediatric patients with non-Hodgkin lymphoma treated with CD19 chimeric antigen receptor (CAR) T-cells [abstract]. Br J Haematol 2018;182(Suppl 1): Abstract 29

44. Taraseviciute A, Broglie L, Phelan R, et al. What is the role of hematopoietic cell transplantation (HCT) for pediatric acute lymphoblastic leukemia (ALL) in the age of chimeric antigen receptor T-cell (CART) therapy? J Pediatr Hematol Oncol 2019;41:337-344.

45. Kochenderfer JN, Dudley ME, Carpenter RO, et al. Donor-derived CD19-targeted T cells cause regression of malignancy persisting after allogeneic hematopoietic stem cell transplantation. Blood 2013;122: 4129-4139.

46. Brudno JN, Somerville RP, Shi V, et al. Allogeneic T cells that express an anti-CD19 chimeric antigen receptor induce remissions of B-Cell malignancies that progress after allogeneic hematopoietic stem-cell transplantation without causing graft-versus-host disease. J Clin Oncol 2016;34:1112-1121.

47. Philip T, Hartmann O, Biron P, et al. High-dose therapy and autologous bone marrow transplantation in partial remission after first-line induction therapy for diffuse non-Hodgkin's lymphoma. J Clin Oncol 1988;6: 1118-1124.

48. Loiseau HA, Hartmann O, Valteau D, et al. High-dose chemotherapy containing busulfan followed by bone marrow transplantation in 24 children with refractory or relapsed non-Hodgkin's lymphoma. Bone Marrow Transplant 1991;8:465-472.

49. Bureo $E$, Ortega JJ, Muñoz A, et al. Bone marrow transplantation in 46 pediatric patients with non-Hodgkin's lymphoma. Bone Marrow Transplant 1995;15:353-359

50. Ladenstein R, Pearce R, Hartmann O, et al. High-dose chemotherapy with autologous bone marrow rescue in children with poor-risk Burkitt's lymphoma: a report from the European Lymphoma Bone Marrow Transplantation Registry. Blood 1997;90:2921-2930.

51. Fanin R, Ruiz de Elvira MC, Sperotto A, et al. Autologous stem cell transplantation for T and null cell CD30-positive anaplastic large cell lymphoma: analysis of 64 adult and paediatric cases reported to the European Group for Blood and Marrow Transplantation (EBMT). Bone Marrow Transplant 1999;23:437-442.

52. Kobrinsky NL, Sposto R, Shah NR, et al. Outcomes of treatment of children and adolescents with recurrent non-Hodgkin's lymphoma and Hodgkin's disease with dexamethasone, etoposide, cisplatin, cytarabine, and I-asparaginase, maintenance chemotherapy, and transplantation: Children's Cancer Group Study CCG-5912. J Clin Oncol 2001;19: 2390-2396.

53. Levine JE, Harris RE, Loberiza FR Jr, et al. A comparison of allogeneic and autologous bone marrow transplantation for lymphoblastic lymphoma. Blood 2003:101:2476-2482.

54. Woessmann W, Peters C, Lenhard M, et al. Allogeneic haematopoietic stem cell transplantation in relapsed or refractory anaplastic large cell lymphoma of children and adolescents-a Berlin-Frankfurt-Münster group report. Br J Haematol 2006;133:176-182.

55. Won SC, Han JW, Kwon SY, et al. Autologous peripheral blood stem cell transplantation in children with non-Hodgkin's lymphoma: a report from the Korean society of pediatric hematology-oncology. Ann Hematol 2006 85:787-794

56. Giulino-Roth L, Ricafort R, Kernan NA, et al. Ten-year follow-up of pediatric patients with non-Hodgkin lymphoma treated with allogeneic or autologous stem cell transplantation. Pediatr Blood Cancer 2013;60: 2018-2024. 